\title{
An Attempt at Periodizing Recent (Southern African) Afrikaans Poetry (1955-2012)
}

\author{
By Bernard Odendaal ${ }^{*}$
}

\begin{abstract}
A perspective is offered on Afrikaans poetry between 1955 and 2012. This literary era overlaps with the socio-political era of Apartheid and the struggle against it, as well as the consequent establishment of democracy in South Africa. An approach based on systems theory is combined with views that South African literature may be seen as a "story-scape" of major discourses. Both intra- and extra-systemic factors have influenced trends in Afrikaans poetry. Pressing Southern African socio-political issues have helped to shape the said Afrikaans poetry era into three distinctive periods. The first may be labelled the "literature of the Sixties" (a belated flowering of modernism in Afrikaans). The "Soweto riots" of 1976 then steered South Africa towards sociopolitical reform. A second poetry period, characterized by tensions between aesthetic and socio-political considerations, therefore covers the years up to the democratic elections of 1994. Since then, discourses like the postcolonial, postmodern and ecological have become centralized.
\end{abstract}

Keywords: Afrikaans poetry, Periodization, Recent era.

\section{Introduction: A Bird's-Eye View of the History of Afrikaans and Afrikaans Poetry before 1955}

Afrikaans is a Southern African language, named after the continent on which it developed. It evolved from $17^{\text {th }}$ century Dutch in the contact situation between Dutch and other settlers of European descent, the indigenous Khoikhoi cattle herders and other indigenous African peoples, as well as the Malaysian slaves who were imported to what was formerly known as the Cape of Good Hope. "Proto-Afrikaans"1 or "Cape Dutch" (Ponelis 1993, Van Rensburg 1997, Carstens 2013: 26) therefore showed characteristics of various European and African languages (Carstens 2013).

The Cape of Good Hope became a British colony in 1806. It was soon followed by aggressive efforts at anglicizing the colony, and these events motivated about 15,000 rural, white Afrikaans speaking settlers (calling themselves Afrikaners or Boers) to undertake the so-called Great Trek northwards between 1835 and 1845. Two Boer republics were thus established outside the British colony. A second reaction by the Afrikaners, in the last quarter of the nineteenth century, was to cultivate Afrikaans in written form; to shape it into a language of literature and culture. In fact, white speakers of Afrikaans appropriated the language as a symbol of their national identity

\footnotetext{
* Professor, North-West University (Potchefstroom Campus), South Africa.

${ }^{1}$ Quotes from Afrikaans sources (see References) have been translated into English by the author of this article.
} 
(Carstens 2013: 28), thereby opposing British cultural oppression. This period in time, known as the era of the First Afrikaans Language Movement, is usually deemed (e.g. by Antonissen, s.a.; Dekker 1967, Kannemeyer 1978, 1983, 1988 and 2005) to represent the true beginning of Afrikaans literary history.

The Anglo-Boer War (1899-1902) between the British Empire and the two Boer republics culminated, initially, in political, material and psychological calamity for the Afrikaners (Carstens 2013: 28). Renewed efforts at anglicizing the population inspired Afrikaner nationalistic sentiments, thereby triggering a Second Language Movement. The process of the standardization of Afrikaans was undertaken, and the language obtained status as one of the official languages of a unified South Africa in 1925. The formation and perpetuation of an Afrikaans literary canon took shape in earnest during these years (cf. Van Coller and Odendaal 2005b: 24-26). The spirit of energetic Afrikaner identity formation and national awareness was clearly reflected in the literary sphere. It was deemed the natural task of the young Afrikaans writers of this era to develop Afrikaans into a sensitive instrument with which the deepest emotions of the nation and the individual could be captured (Van Coller and Odendaal 2005b: 25).

The next three decades constituted a period of consolidation in this regard. Politically, the Afrikaners gained confidence, did not feel inferior to the English anymore and eventually achieved political dominance when the National Party won the 1948 general election. In the literary sphere, the consolidation process resulted in, for example, a number of literary historiographies and popular poetry anthologies being published.

In the mid-1930s a new phase in Afrikaans literary history dawned. A new generation of poets, later known as the "Dertigers" (i.e. Poets of the Nineteen Thirties), no longer wished to be cast in the traditional nationalistic mould. They argued that the best way to serve Afrikaans literature was to lift its aesthetic standard to an international level. N.P. van Wyk Louw was the foremost poet among them, also the most skilful and powerful formulator of the ideals of this generation. He emphasized the separate, African identity of Afrikaans, but also stressed the European tradition from which Afrikaans originated, stating that Afrikaans incorporated both the "great, serene West" and "magical Africa" (Louw 1961: 155).

In the next decade-and-a-half the poetry of, among others, D.J. Opperman, built on the work of the Poets of the Thirties. It still reflected nationalistic trends and themes, but also took on "objectively" figurative characteristics, tending to be semantically compacted and stratified; thus, more or less transforming Afrikaans poetry into a (belated) "high modernist" mould.

This prepared it for the developments of which I wish to offer an overview in the rest of this article. 


\section{A Few Notes on the Approach Underlying this Perspective on Afrikaans Poetry between 1955 and 2012}

I was invited to write a perspective on the era of Afrikaans poetry since 1955 for a new edition of the literary historiography Perspektief en profiel. ' $n$ Afrikaanse literatuurgeskiedenis (Perspective and Profile. A History of Afrikaans Literature). That task was undertaken during the first semester of 2013 - which explains why the cut-off date of the era in question is 2012.

My primary focus is on the production segment of Afrikaans poetry as a literary sub-system in the said era. An approach broadly based on systems theory will therefore be taken, combining it with views (De Kock 2005, Hein Viljoen 2010) that South African literature, in general, may be seen as a "storyscape" of major "adventures" or discourses. The discursive manifestations identified by Hein Viljoen (2010), for example the national, the postcolonial, the ecological, the semiotic, the feministic, the erotic, the religious, the modern and postmodern, served as a kind of screen in discovering and collocating thematic, ideological or poetical preoccupations within the Afrikaans poetry system of the past fifty to sixty years. I have not necessarily employed the terms used by Hein Viljoen in describing such phenomena, but the concept of a discursive screen allowed me to keep track of evolving thematic preoccupations, as well as of changes in poetic style and form (the "semiotic adventure"). In this way, it became possible to identify literary historic transitions and, therefore, the representational constructions (Hein Viljoen 1990: 3) or socio-codes (Fokkema 1984: 5-8, Du Plooy 1990: 70-71) underlying the three literary periods which are discussed in this overview.

Periodization necessarily entails the postulation of "a (fictional) identity and unity" (Hein Viljoen 1990: 3); it does have a more or less reductionistic effect, but it also allows one to get a grip on the diversity of the literature produced during a specific era.

Afrikaans poetry of the past six decades is therefore viewed as an integral part of the Afrikaans literary system, with its own identity and dynamics, but which has been significantly influenced by developments in other literatures, as well as in the socio-political and cultural spheres. Both intra- and extra-systemic factors have helped shape trends in Afrikaans poetry, occasionally causing them to contrast with developments in, for example, South African English literature.

The influence of pressing Southern African socio-political issues during the era under consideration, however, particularly vindicates the distinction of three Afrikaans poetry periods. The first corresponds with what is often labelled as the "literature of the Sixties" (a full flowering of international modernism in Afrikaans), reaching into the mid-1970s. The "Soweto riots" of 1976 - an uprising of black people in the so-called townships against the white nationalist government of the time - then steered South Africa onto an irreversible track towards socio-political reform. The second poetry period covers the years up to the first fully democratic South African elections of 1994, and is characterized by tensions between aesthetic considerations and the need for direct socio-political engagement. 
The latest period coincides with the era after Apartheid. Thematic focal points, such as the postcolonial and postmodern discourses, and ecological engagement, have become centralized. The de-isolation of Afrikaans culture, and changes regarding the publishing trade, have also left their marks on Afrikaans poetry.

\section{The "Sestigers" (Afrikaans Poets of the Sixties) and Further Developments Until the Mid-1970s}

For Afrikaans poetry, the "Movement of the Sixties" (or "Sixty" for short, as this period of literary innovation in Afrikaans is alternatively called) was not the clear divide in terms of quality and professionalism, between before and after, as it was for Afrikaans prose fiction and, to a certain extent, Afrikaans drama (John s.a[I]: 1). That "innovative heyday" (Van Vuuren 2001: 33) for Afrikaans poetry lay with the Poets of the Thirties and their immediate successors. Nevertheless, poetry works were produced by the Poets of the Sixties which at least equaled, if not surpassed, the quality of the best that was created in such fields as prose fiction (Kannemeyer 2005: 276-277).

In fact, the critic A.P. Grové (1980: 8) was of the opinion that the novelties in spirit and style of Sixty had nowhere else been shown breaking through more definitively than in the two poetry volumes Peter Blum had published in 1955 and 1958, respectively. Blum was, according to the literary historiographer Antonissen (s.a.: 329), the "first among the younger poets to leave both the metaphysics and the elementarism of Forty and the confessional attitude of Thirty behind him".

Before looking at the poetry of the debutants, I wish to emphasize the more or less obvious: that the production and influence by most of the Afrikaans poets from before 1955, continued far into the era in question. Kannemeyer (2005: 275), among others, argues that the Afrikaans poetry scene of the late 1950s and of the 1960s was still dominated by the likes of N.P. van Wyk Louw and D.J. Opperman; in fact, Louw en Opperman stood at the center of the whole of the South African literary world until well into the 1970s (Kannemeyer 2007: 28).

One of the outstanding characteristics of the poetry by a number of forerunners of the Poets of the Sixties (Peter Blum, Boerneef, P.J. Philander, George Louw, Ingrid Jonker and others) is described by John (s.a.[I]: 3) as a "(re)discovery of the South African reality". The latter is seen as encompassing the earthly, rural ways of the country's various population groups, but also socio-political topicalities such as the position and way of life of the so-called "Coloured" (indigenous, Afrikaans speaking Khoisan people, but also of racially mixed descent). Other characteristics include accompanying stylistic shifts toward the colloquial language and the regionally typical, as well as toward the playful and the humorous.

Kannemeyer $(2005: 268-269,275)$ is of the opinion that the reform of Sixty was enacted in two movements. At first, in the 1960s, a broadening of thematic preoccupations took place: a growth away from the "traditional [...] motives" of 
Afrikaans culture, towards a more marked "internationalist" attitude (Kannemeyer 2005: 275), which coincided with the implementation of new literary techniques and forms. Both Van Vuuren (1999: 249) and Du Plooy (1990: 90-92) indicate that this phase in Afrikaans literature may be viewed as the era of the full flowering of international modernism in it, characterized by "metalingual scepticism, epistemological misgiving, intellectual detachment and irony, with topics like the sexual, the psychological, science and technology". Experimentation with poetic technique and with typography, often tending towards "an amorphous, looser type of versification" (Foster 2000: 3), accompanied such thematic preoccupations; a return to "stricter formal discipline" (Kannemeyer 2005: 275) was, however, seen in the 1970s.

An intensified "interest for the political and social in the broadest sense and an exploration of the African continent" (Kannemeyer 2005: 269) marked the second "movement" during the period in question; a development which, seen in the context of the whole of the Afrikaans literary system, gained even greater prominence in the 1970s.

Both these phases of renewal were embedded in socio-political, economic and broader cultural developments of crucial importance - influencing, to a greater extent than ever before, "the shaping of the Afrikaans poetry scene" (John s.a. [II]: 2). On the one hand, both the experiencing of a period of economic burgeoning since the 1950s and of political independence since South Africa had become a republic in 1961, left Afrikaners with "a kind of euphoria" (Kannemeyer 2005: 262) of power, prosperity and cultural unity. The illusion was upheld that the political problems around the issues of race and colour would be solved by the policies of Apartheid, i.e. through a dispensation of "separate development" in separate suburbs and "independent" homelands within a "communal market" for Southern African states (Kannemeyer 2005: 265).

The economic prosperity, however, and the consequent rizing rates of urbanization and tertiary educational experience among Afrikaners, accompanied by their exposure to international trends and developments in politics and culture, caused growing numbers of the intelligentsia among their ranks to become critical of the Apartheid views and policies (Giliomee 2003: 497-498). Cultural boycotts by the likes of The Netherlands, constituting the loss of an important, postcolonial point of reference for Afrikaner intellectuals and literati, strengthened their feelings of alienation (Van Coller and Odendaal 2005b: 3234). In a sense, it became the ideology of Sixty to break down the many taboos and prejudices of the Afrikaner establishment of the time (Kannemeyer 2005: 268).

Parallel to these developments within the Afrikaner community, stood the growing criticism of and rebellion against the Apartheid system by other communities within South Africa, as well as by the international community. This climaxed in "a transformation of passive black resistance into violent revolt" (Van Vuuren 1999: 246), such as the so-called "Soweto-riots" of 1976. The Apartheid government met these challenges by, on the one hand, mobilizing its armed forces, banning revolutionary parties and announcing a state of emergency. On the other hand, questions raised about (the quality of) the 
survival of the Afrikaners and of Afrikaans (Giliomee 2003: 469) compelled the government to introduce some policy reforms which, in certain respects, moved away from racial discrimination (Kannemeyer 2005: 265).

In the Afrikaans poetry of the period 1955-1976, the discourse around national identity therefore became a leading one. A distinction was made by the novelist and critic André P. Brink (1992: 39, 40) between "actuality" poetry and "engaged" poetry in this regard; the former constitutes a "representation of a recognizable piece of actuality" and the latter serves as an indication that the author stands as an "antagonist of the conservative, petrifying powers in society", with the clear vision of getting it "transformed". Most of the Afrikaans poetry engaging with national issues in this period, manifested either as satire or as harsh criticism of the Apartheid ideology and its resulting sociopolitical practices. Adam Small and Breyten Breytenbach are probably the most important names in this regard. Small employed the so-called Cape vernacular of Afrikaans, spoken by the majority of Coloured people in the south-western parts of South Africa, with impressive effect by expressing the collective feelings of protest of those suffering most under the Apartheid system. Breytenbach, a white poet who was not allowed to return to South Africa after marrying a woman of Vietnamese descent in France in 1965 (Vietnamese people were classified as non-whites by the Apartheid state), became probably the fiercest poet-critic of the injustices of the Afrikaner nationalist government. Found guilty on charges of terrorist activities and sentenced to imprisonment from 1976 to 1983, he also developed into the most important writer of "prison poetry" in Afrikaans (Van Vuuren 1999: 279).

"Mensverse" (human verse) came to be a kind of catch-word in signalling the poetic pre-occupation with the humanitarian issues prevalent in Apartheid South Africa. Themes, such as the destiny of humanity, the journey-like nature of (the individual) human life, the (African) origin of man and empathy with the fate of the marginalized (and juvenile), therefore also enjoyed prominence in the work of many other Poets of the Sixties (Wilma Stockenström, Lina Spies, Wilhelm Knobel and others). Often coupled with such issues, was a predominantly loving protrayal of earthly-rural, folksy and regional identities in the poetry of the likes of George Weideman, Dolf van Niekerk and Pieter W. Grobbelaar. The voices of these poets thus often resonated with those of the supra-personal, collective identities, underlining the "actuality"-nature (Brink 1992) of such poetry.

Opposed to the latter, was the manner in which the experience of rapid urbanization resonated in the Afrikaans poetry of this period. Feelings of alienation and anonymity, of the artificiality and routine nature of the modern existence, came to be expressed in increasing numbers of poetry volumes. More frequently than before, references were made to the mass media, mass culture and consumerism (cf. John s.a.[I]: 2, Van Vuuren 1999: 248); for example in the poetry of Stephan Bouwer and Wessel Pretorius.

In accordance with contemporary international trends, and concurring with the ever stronger focus on marginalised identities in a post-colonial world (John s.d.[I]: 2), an emphasis on gender also became apparent. Women, in particular, 
emerged as leading poetic voices (cf. Spies 1999, Van Niekerk 1999, Lourens 2011). The socio-political implications of being female and a female poet - the questioning of all factors inhibiting female freedom, specifically in the African context (Conradie 1996) - became a burning issue in the work of, in particular, Antjie Krog. Until 1980 however, the situation in South Africa was still largely repressive of the expression of the gay identity (Cochrane 2008).

(Erotic) love found its ever favoured expression in the work of almost all the debutants of this period, with Breyten Breytenbach, Marlise Joubert, Antjie Krog, George Weideman and Fanie Olivier drawing the most attention. Poets earning increasingly important places in the tradition of Afrikaans religious poetry, also caught the spotlight. In general, these religious expressions tended to be of an individualistic nature, allowing (in the work of Lina Spies and M.M. Walters, for example) for critical or satirical attitudes towards the Protestant Christian views that had traditionally dominated Afrikaans poetry. Alternative religious experiences, such as the Zen-Buddhistic in the work of Breytenbach, and the Judaic (Johan de Jager), also found expression.

Breyten Breytenbach developed into probably the most central figure in the Afrikaans poetry system since his debut in 1964. On both thematic and formal levels (as an innovative practioner of free verse techniques), he came to play a leading role, while his high public profile and his provocative statements with reference to ideological, socio-political and poetical issues (Galloway 1990) also contributed to his influential position. Louise Viljoen (2003 and 2009a), for instance, pointed out that the work of at least 25 Afrikaans poets debuting since the 1960s, show traces of being influenced by, or being conversant with, his oeuvre. Dozens of national and international literary awards further attest to the esteem in which he was (and still is) held.

\section{Developments in Afrikaans Poetry between 1976 and 1994}

As pointed out previously, 1976 was the year in which the so-called "Soweto-riots" flared up, followed by "firm and harsh" (Giliomee 2012b: 408) responses by the Apartheid government. Although sparked by the Afrikaner nationalist government's decision to import Afrikaans as a medium of tuition into certain black schools, a growing dissatisfaction with the educational and socio-political dispensation in general lay behind the violent rebellion (Grobler 2012: 383). The consequence for Afrikaans, however, was that, in the eyes of the victims of the system, the language became associated with humiliation, injustice and violence - a consequence that is felt even in the current South African dispensation, i.e. in the marked indifference, or a certain animosity, towards the language (Van Vuuren 1999: 247, Kannemeyer 2005: 553-555).

International criticism, economic disinvestment and cultural and sports boycotts intensified to such an extent that towards the late 1980s, it became apparent that the South African dispensation could no longer be maintained. The country was also isolated militarily, and had to wage a costly "Border War" (also known as the South African Bush War) against revolutionary infiltrators on the 
northern borders of South Africa and Namibia (then still known as South-West Africa), and into Angola. Afrikaner intellectuals became even harsher in their criticism of the system, inspiring influential figures in the National Party itself to increasingly lean towards reformation (Giliomee 2012a: 397).

The isolation was also felt in the literary field. The cultural exchange between the Afrikaans and Dutch literary systems, for example, came to a halt (Van Coller and Odendaal, 2005b: 34). In certain respects, the Afrikaans system was also at loggerheads with the South African English system. Differences in poetical views regarding the relative values accorded to "content" vs. "form", to the "specific" vs. the "universal", to "societal involvement" vs. "the personal", or to an African or European orientation, reflected sometimes divergent views on the socio-political relevance of literature (Galloway and Steenberg 1993: 1-2).

It is against this background that I wish to conclude that the intensified preoccupation with South African actualities in Afrikaans literature after 1976 introduced a new literary period, characterized by "new themes and motives" (Kannemeyer 2005: 560). Poetic manifestations of these developments were the "struggle poetry of many coloured poets in the dialect of the Cape Flats" and of "exiles", as well the marked "political actuality" in the work of poets, such as Breytenbach and Krog. The "pressing reality" (Roodt 1991: 3) of South African circumstances and accompanying values such as "life" and "man", rather than "art" (John s.a.[II]: 1), were foregrounded with even more urgency than in the poetry of the Movement of the Sixties. In the field of literary criticism, a parallel development was the "new paradigm" of "engaged ideacriticism" (Johl 1986: ix, xi), moderated however, by the influence of a global interest in literary theory in the second half of the 1980s (Galloway and Steenberg 1993: 2, Du Plooy and Van Schalkwyk 2000: 116).

A relativization of the view that socio-political involvement was a defining characteristic of the Afrikaans poetry of the late 1970s and of the 1980s, is found in the fact that discourses such as those concerning gender, religion and the erotic, were almost equal in importance in the said period. Trends in poetic style and technique (such as the growth in the publication of "more traditionally disciplined poetry" next to more "amorphous verse" - Kannemeyer 2005: 689) were also largely ignored by an approach in which the socio-political was centralized.

However, as an indication of the "contiguity between Afrikaans literature and [the] greater South African society" (Roos 1998: 21), it does make sense to view the years between the Soweto-riots in 1976 and the dawn of a fully democratic South Africa in 1994 as constituting a distinctive period in Afrikaans poetry and in Afrikaans literature in general.

Although the "refusal of the ideology" was not as widespread and the "resistance" not as direct as in the Afrikaans drama and prose fiction of this period (Gilfillan 1991: 51), political repression and the struggle for freedom were "significant themes" (Louise Viljoen 2011: 23) in the work of many Afrikaans poets. Breyten Breytenbach and Antjie Krog, as well as the Cape Flats poets, have already been mentioned in this regard. Dozens more could be named. The titles of anthologies of struggle poetry, such as Aankoms uit die 
skemer (Arriving from the Twilight) and I Qabane Labantu. Poetry in the Emergency, reflects the actualities and the socio-political involvement expressed in such work, while some of the white poets articulated their negative experiences of military conscription and military "border service".

An interesting and significant point of growth was the manner in which cabaret and song texts were utilized by poets such as Hennie Aucamp, Etienne van Heerden and André Letoit, to comment on socio-political issues. Such work caused the division between poetry as "high" (elitist) and songwriting as "low" cultural expressions to be undermined (Ohlhoff 1999: 263). This was a development that gained in momentum after 1994, and which would assist in countering the marginalization of Afrikaans poetry within the context of the greater South African literary system.

The voicing of the specifically female experience of life and the world, continued to gain discursive prominence, taking on a political complexion when related to the feministic discourse. Nearly a third of the debutants in this period of Afrikaans poetry were female (Foster 2000: 4). Contrary to the situation before 1980, the growing frankness in expressing homosexuality and gay eroticism (especially in the work of Johann de Lange and Joan Hambidge) became one of the defining thematic growth points of the period in question albeit, apart from the occasional emphasis on glaring loneliness as a trait of the gay condition, with muted socio-political implications.

In the face of the burning socio-political issues of the time, the (universal) ideal of self-discovery and self-realization (the "liberal adventure") seemed to gain even greater importance than usual. The unwavering importance of religious and love poetry, epitomized by the repeated publication of popular collections (Nienaber and Nienaber-Luitingh 1987, Olivier 1986 and 1992) on these themes, were, in a certain sense, illustrative of this. Two of the most important religious Afrikaans poets ever, both with a bent towards mysticism, namely T.T. Cloete and Sheila Cussons, debuted in these years (among other religious poets). A (more or less masked) "autobiographical element" was also to be observed in much of the poetry of this period (Van Vuuren 1999: 282286, Hugo 1996: 9). In certain cases, for example in the work of Antjie Krog, the unveiled autobiographical approach and the explicit expression of matters concerning sexuality, served to emphasize an "anti-establishment" ethos (Botha 2011).

Another expression of the emphasis on "life" and "man" (John s.a.[II]: 1) in this period, was the way in which certain poets strived to give voice to the "neglected or marginalized figures" (Foster 2000: 5) of South African history and society. Representations of the ways of life of the indigenous Khoi, San and Griqua peoples were illustrative of this trend. The portrayal of the culture of the latter group in the work of Hans du Plessis and Thomas Deacon was stylistically marked by the effective use of the colloquial variety of Afrikaans spoken by the Griqua. Another case in point was the portrayal, written in a colloquial variety of Afrikaans characterized by its mixing with English, of a more or less displaced, troubadour-like Afrikaner figure, such as in the work of Koos Kombuis and Gert 
Vlok Nel. The latter represented a flux between association and dissociation with Afrikaner identity.

Although man's love and care for nature had been an important theme right from the early history of Afrikaans poetry, the discourse around ecological issues, and of man's resposibilities to the environment (in the broadest sense of the word), grew to be of striking presence in the work of a number of poets debuting in the late 1970s and 1980s. Johann Lodewyk Marais appeared as a leading poet in this regard, among other roles acting as compiler and co-compiler of two influential anthologies on the subject in the 1990s.

Some Afrikaans literary critics (Foster and Louise Viljoen 1997, Hein Viljoen 2010, Ohlhoff 1999: 198-199, Louise Viljoen 2009a) have argued that the concept of the postmodern, although relatively poorly defined with reference to Afrikaans poetry (Ohlhoff 1999: 197, Foster 2000, Engelbrecht 2006: 10-12), is relevant to a better understanding of an important body of Afrikaans poetry from the period discussed here. Well-known characteristics of the postmodern condition (as formulated, for instance, by Jean Baudrillard), and which serve to define key volumes of Afrikaans poetry from the last quarter of the twentieth century, include: the relativizing of the self and of the notions of identity, truth and history; stylistic and thematic variety, with re-use and recycling thereof as a further trait; and the undermining of differentiations between "high" and "low" art, with heterogenity and mixing as contributing elements. Works by poets such as the following have been discussed by Afrikaans scholars in this regard: Antjie Krog (Louise Viljoen 2009b: 29-53, Gilfillan 1991: 52), Breyten Breytenbach (Gilfillan 1991: 51, Van Vuuren 1999: 279), Wilma Stockenström (Foster 2001), Joan Hambidge (Van Vuuren 1999: 288), H.J. Pieterse (Du Plooy 2006: 424, Jacobs 2010: 5-7) and Louis Esterhuizen.

As I have mentioned previously, the development in the 1980s concerning poetic technique and form, observed by a number of commentators (John s.a.[II]: 2, Gilfillan 1991: 54, Ohlhoff 1999: 197, Kannemeyer 2005: 689), involved the rise of a more disciplined, often fixed type of verse. The development, sometimes manifesting in verse showing characteristics of poetry of wit, was all the more striking because it contrasted with the often "amorphous" verse type which had dominated in the 1960s and 1970s. Major contributors in this regard include Daniel Hugo, Tom Gouws and T.T. Cloete. Some critics (Hugo 1996, Hambidge 1993) were of the opinion that the latter poet had been the most dominant figure in the Afrikaans poetry of the 1980s, exerting a striking influence - technically and metaphysically (Hambidge 1993: 8) - on a number of contemporaries and successors.

\section{Developments in Afrikaans Poetry since 1994}

Towards the end of the 1980s it was apparent to most of the white South Africans themselves that the Apartheid system had become morally indefensible. Parallel initiatives were taken by independent Afrikaner intellectuals and by leaders within the ranks of the National Party to meet with representatives of 
banned organizations, such as the African National Congress (ANC), in order to discuss the possibilities of a future political settlement (Giliomee 2012b: 413414). The fall of the Berlin Wall in late 1989, signalling the end of the global influence of communism and, therefore, of an important excuse for continuing the old dispensation in Southern Africa, was the inspiration behind some momentous decisions taken by the Apartheid government. In February 1990 it was announced that all South African freedom movements would be unbanned and their imprisoned leaders freed. A negotiational process was set underway, resulting in the establishment of a fully democratic Republic of South Africa in 1994, with Nelson Mandela, leader of the ANC, as the head of state.

As for other spheres, these political developments led to intensified intersystemic activities for Afrikaans literature, both on the national and international levels. An era of rapprochement from the Dutch-speaking world was initiated, particularly by the Dutch Language Union (cf. Van Coller and Odendaal 2005b: 35-37). These initiatives resulted in reciprocal visits by scholars and writers and in systemic interaction by means of translation. The broadening of horizons for Afrikaans poetry, however, also included a revitalized literary interchange with other languages, including North American English, German and various African languages (Crous 2009: 215).

Another important factor emanating from the formation of the new South Africa was the ideal of an all-inclusive, national literary system. Since English had become the preferred working language of the new dispensation, it was clear that literature written in English would occupy a central position in such a construction (cf. Van Coller and Odendaal 2007). Certain eminent Afrikaans writers, such as Antjie Krog (labelled by some commentators as the probable "unofficial Poet Laureate" of the New South Africa - cf. Van Coller and Odendaal 2003), thus commenced writing some of their books in English. Collections from the poetry of a number of Afrikaans writers were made available in the increasingly dominant language. An alternative strategy was to change the image of insulation the Afrikaans system had had, i.e. by translating poetry from other indigenous languages into it (cf. Odendaal 2006: 138-139). The repeatedly expressed desire to hear more "brown" and "black" voices in Afrikaans (Almano 2001, Burger 2002, Adendorff 2003: 101-102, De Jager 2005), and the plurality of initiatives taken to encourage publication of such works, further attested to the need for transformation of the system.

The advent of the new South African dispensation also impacted the Afrikaans publication industry. Afrikaans had lost its status as the (only) second official language next to English, causing a significant decrease in student numbers in Afrikaans classes and at Afrikaans teaching institutions. A collapse in the Afrikaans book prescription market was the result (Venter and Galloway 2003: 7, Adendorff 2003: 73-74). Feeling the economic pressure, publishers of poetry therefore focussed much of their attention on the publication of poetry anthologies of various types, allowing one to view the 1990s, to a certain extent, as a time of surveying the achievement of Afrikaans poetry (Odendaal 2001). Such developments, and the accompanying pessimism about the future of poetry publication, were firstly, countered by a flourishing in the numbers of recitals 
new work enjoyed at cultural and literary festivals; secondly, many new settings of poetry to music, performed at similar opportunities and/or made available in recorded format, started to appear. These popularizing initiatives narrowed the traditional divide between the Afrikaans music and poetry systems (Bosman 2003, Adendorff 2003). The dominance of the elitist, aesthetic view of literature was put up for discussion anew, as was the multi-faceted nature of the literary system (Adendorff 2003, Klopper 2009).

New editions of the leading literary-historical anthology of Afrikaans poetry, Groot verseboek (Great Book of Verse), offer a concrete example of this "democratizing" trend in Afrikaans poetry since 1994. The two editions compiled by André P. Brink $(2000,2008)$ during the period under discussion, were much more comprehensive than the editions compiled by D.J. Opperman in earlier decades. Brink also widened his view on what constituted Afrikaans poetry by also collecting some song texts and translated poems in his anthology, including texts which had formerly appeared only in occasional publications of an anthological nature (not in solo volumes) - inclusions which Opperman would not have considered.

Other initiatives stimulating the production of new Afrikaans poetry, especially since 2000, included an increase in the numbers of poetry competitions and workshops on offer (also via the internet); of meritorious and incentive prizes awarded; and of publishers becoming involved in the poetry market (again). Consequently, the position of "serious" Afrikaans poetry (Louise Viljoen 2011: 17) in the literature production segment improved significantly to such an extent that it may, at present, even be viewed as a "privileged" Afrikaans literary genre (Kleyn 2008: 18).

Its vitality and variety were illustrated in more than one way. There was a growing presence of verse written in non-standard, colloquial varieties of Afrikaans, made prominent by the inclusion of a relatively substantial amount of such poetry in comprehensive anthologies, such as the said Great Book of Verse and one compiled by the eminent Dutch anthologist, Gerrit Komrij (1999). In the first decade of the new millennium, two - more or less opposing - trends in versification drew special attention: a more accessible verse type, further characterized by a "narrative turn" with "anecdotal elements and a 'parlando' style" (Louise Viljoen 2011: 18); and a revival of the tradition of the more hermetic kind of poetry, often characterized by "dense" imagery, extensive fields of reference and intertextuality, innovative structuring and a play on words (Louise Viljoen 2011: 20). Lastly, several polemics in the mass media and on internet regarding the nature and function of literary criticism, and generally also touching on poetical issues, attested to a lively interest in, and a variety of viewpoints on, such matters.

On the thematic level, the volume and variety of voicings of experiences and views concerning religion, love and sex, gender and ecological issues, had not abated since the previous period; on the contrary, these increased. "Green" poetry dominated many a collection; in the work of poets such as T.T. Cloete, P.W. Buys, Ilse van Staden and Trienke Laurie ecological issues were often seen in a religious light. The autobiographical turn registered in discussing the 
period before 1994, was continued robustly. It often served as an apparent expression of the pressing identity issue among South Africans; therefore, also among Afrikaners in the new dispensation - a subject to which I shall return shortly. At the same time, however, it was a poetic manifestation of the "authenticity pursuit" in Afrikaans literature since the early 1990s, i.e. of depicting South Africans' experiences of their realities authentically (Du Plooy and Van Schalkwyk 2000: 127). It stood parallel to a contemporaneous growth in the publication of ego-documents and works focussing on the "private ache" in the field of Afrikaans prose fiction (cf. Du Plooy 2001: 14-31, Van Coller 2002: 315-318). A number of more or less autobiographical poetry collections which have appeared around and since the turn of the millennium, may be decribed as "late work" (Van Vuuren 2011). Many such poets had made their debuts in the 1960s and 1970s; although depictions of elderliness and sickness were not new to Afrikaans poetry, by the turn of the millennium some of these poets (such as Barend Toerien, Petra Müller, Pirow Bekker and Breyten Breytenbach) contributed significantly to the marked status "late" poetry has been enjoying in the Afrikaans system since then.

The socio-political changes of 1990-1994 gave a new impetus, in the form of a postcolonial reflection on identity (Crous 2009: 200), to the "national adventure" as a continual thematic preoccupation in Afrikaans poetry. Manifestations of it may be found in the already mentioned initiatives taken in trying to "democratize" the system; for example, by greater toleration concerning the use of colloquial language varieties. The transformation of South African society towards greater integration, as well as its inhabitants' experiences of the increasingly global nature of economics and mass culture have, on the one hand, encouraged Afrikaans poets to keep on writing poetry of recollection, often in a nostalgic tone. Another development was a growth in the popularity of poetry reflecting particular regional or group identities and realities. As pointed out by Van Vuuren (1999: 297), the latter trends built on examples that had already been set by Afrikaans poets from as early as the 1950s.

The identity issue, "often depicted in terms of physical and ideological spaces" (De Beer and Du Plooy 2011: 88), was repeatedly linked to the problem of the relativity of human perspective in such poems. This was also true of the motif of the journey, or of wandering. Such a linking was even more marked than in the period before 1994 (De Beer and Du Plooy 2011: 89-92), when a number of Afrikaans poets in exile had expressed their feelings of displacement. A few of these former exiles, encouraged by the transformations of the early 1990s, returned to South Africa, voicing their (mostly) affectionate (re)discovery of the country and its people.

Contrasting with the latter sentiments was the apparent growth in the expression of pessimism about the preservation and further development of (Afrikaans) culture in the new South Africa. Doubts about the survival of Afrikaans as a language and of the purpose and value of the poetry accompanied this (cf. Louise Viljoen 2011: 22-23). The cultural pessimism should be seen as an extension of the thematic elements that had already manifested earlier in Afrikaans poetry; for example, the motifs of relativity, disintegration and 
divestment that Cloete (1980: 116-118) had identified, or the postmodern denial of final, closed meaning which Foster and Viljoen (1997: xxvi) had shown to be a characteristic of Afrikaans poetry since the Movement of the Sixties. In the work of a number of poets since 1994, however, the cultural doubts resulted in more optimistic outcomes. The metamorphosis of the self or the culture group was a central marker of the thematic development in such works.

A less transcendent reaction to the "new injustices and new evils" of postApartheid South Africa (according to the cover text of the anthology Nuwe verset [New Resistance] - Hugo et al. 2000), was the growing discontent voiced by numerous poets about socio-political developments. Such developments included the increasing inaccessibility of educational and occupational possibilities to, for instance, speakers of Afrikaans; the decay of infrastructure, morality and the environment; and the increasing (violent) crime and (inverted) racism. The third section of the said anthology, titled "We told the truth", reflects a claim to frankness in this regard, but also to the expression of values or conditions for a workable coexistence in South Africa. A democratically constructive resistance was therefore implied. On the evidence of the variety of social groups which were represented by the poets adding their voices to such resistive expressions, Adendorff (2003: 102, in imitation of Foster 2000: 4) concludes that it constituted a continuation of "the so-called struggle poetry of the 1970 s and 1980s".

\section{Closing Remarks}

As explained earlier in this article, the identification of three periods in the history of Afrikaans poetry of the past fifty to sixty years is largely based on the observance of the impacts that socio-political revolutions in the Southern African context have had on almost all walks of life in the region, including on its literature.

The fact that each of the three periods identified in this way, covers a poetry publication history of approximately twenty years - the all too accidental, artificial symmetry of it - already indicates the provisional value of the division. 1976 and 1994 are, for example, milestone dates in the history of South Africa; 2012 not. The literary-historic perspective offered here, terminates mid-stream of a still evolving (general and literary) history.

The screen of "adventures" or, rather, broadly continuous thematic and stylistic preoccupations, as well as formal developments in the Afrikaans poetry of the past five to six decades which have been tracked in this article, have not only mediated the recognition of certain literary-historical transitions; they are also illustrative of how both the powers perpetuating tradition and the mainsprings of innovation have been active in the system. Obviously, the system is a robust one, incorporating a relatively impressive variety of participating individuals, groups and institutions. Diverse ideological and poetical trends are being accommodated in it. At present, i.e. after decades of the international boycotting of, especially, the broader Afrikaans cultural 
system, Afrikaans poetry is interacting energetically with other cultures and literatures. It forms part of a mature literature which has gained "such a measure of confidence in its own existence that the system does not need to be protected so meticulously anymore" (Van Coller and Odendaal 2005a: 9).

\section{References}

Adendorff E (2003) Digdebute teen die millenniumwending: 'n Polisistemiese ondersoek (Poetry Debuts by the Turn of the Millennium: A Poly-systemic Investigation). Unpublished MA dissertation, University of Stellenbosch, Stellenbosch.

Almano A (2001) "Swart" Afrikaanse digters en 'n omvattende, inklusiewe SuidAfrikaanse digkuns: 'n Posisiebepaling ("Black" Afrikaans Poets and a Comprehensive, Inclusive South African Poetry System: Determining a Position). Unpublished MA dissertation, University of the Western Cape, Cape Town.

Antonissen R (s.a., third, revised edition; first edition 1955) Die Afrikaanse letterkunde van aanvang tot hede (The Afrikaans Literature from Beginning to Present). Cape Town: Nasou.

Bosman M (2003) Het Afrikaanse rock iets vir die Afrikaanse poësie te sing? (Does Afrikaans Rock Have Something to Sing to Afrikaans Poetry?). Stilet 15(1): 101121.

Botha M (2011) Outobiografie en poësie in Antjie Krog se Gedigte 1989-1995 (Autobiography and Poetry in Antjie Krog's Poems 1998-1995). Stilet 33(2): 121-144.

Brink AP (1992) Betrokke literatuur (Involved Literature) In: Cloete TT (Eds.), Literêre terme en teorië (Literary Terms and Theories). Pretoria: HAUM Literary, pp. 38-41.

Brink AP (Eds.) (2000) Groot Verseboek 2000 (Great Book of Verse 2000). Cape Town: Tafelberg.

Brink AP (Eds.) (2008) Groot Verseboek (Great Book of Verse). Cape Town: Tafelberg.

Burger W (2002) Waar's die nuwe stemme in ons letterkunde? (Where's the New Voices in Our Literature). LitNet Academic. Retrieved from http://goo.gl/d0Tk9H. [Accessed: 30 April 2013].

Carstens W (2013) Die storie van Afrikaans: Perspektiewe op die verlede, hede en toekoms (The Story of Afrikaans: Perspectives on the Past, Present and Future). Tydskrif vir Nederlands en Afrikaans 20(1): 21-49.

Cloete TT (1980) Poësie (Poetry) In: Cloete TT (Eds.), Die Afrikaanse literatuur sedert Sestig (Afrikaans literature since 1960). Goodwood: Nasou Ltd., pp. 115291.

Cochrane N (2008) Stephan Bouwer (1948-1999): 'n Herwaardering met spesifieke verwysing na sy poësie-oeuvre (Stephan Bouwer (1948-1999): A Revaluation with Specific Reference to his Poetry Oeuvre). LitNet Academic 5(1). Retrieved from http://goo.gl/OtydcN. [Accessed: 26 February 2013]

Conradie P (1996) Geslagtelikheid in die Antjie Krog-teks (Gender in the Antjie Krog Text). Cape Town: University of the Western Cape Press.

Crous M (2009) Afrikaans Poetry: New Voices. Current Writing 21(1\&2): 200217. 
De Beer AM, Du Plooy H (2011) Ruimte as tema en metafoor in die poësie van enkele vroulike Afrikaanse digters: 1994-2005 (Space as Theme and Metaphor in the Poetry of an Number of Female Afrikaans Poets: 1994-2005). Literator 32(1): 73-98.

De Jager N (2005) Waar is die nuwe generasie swart Afrikaanse skrywers? (Where Is the New Generation of Black Afrikaans Writers?). LitNet Academic. Retrieved from http://goo.gl/gakcgZ. [Accessed: 30 April 2013]

Dekker G (1967) (twelfth revised print; first print 1935) Afrikaanse literatuurgeskiedenis (Afrikaans Literary History). Cape Town: Nasou.

De Kock L (2005) "Naming of Parts", or, How Things Shape Up in Transcultural Literary History. Literator 26(2): 1-15.

Du Plooy H (1990) Stromings, sosiokodes en representasies (Trends, Socio-codes and Representations). Literator 11(3): 70-94.

Du Plooy H (2001) An Overview of Afrikaans Narrative Texts Published between 1990 and 2000. Stilet 13(2): 14-31.

Du Plooy H (2006) H.J. Pieterse (1960-) In Van Coller HP (Eds.) Perspektief en profiel. 'n Afrikaanse literatuurgeskiedenis, Deel 3 (Perspective and Profile. A History of Afrikaans Literature, Part 3). Pretoria: J.L. van Schaik, pp. 409-427.

Du Plooy H, Van Schalkwyk P (2000) "So is ek, so my lewe": Outentisiteit in die dekade van negentig ("Such am I, Such my Life": Authenticity in the Decade of Ninety). Stilet 12(1): 115-134.

Engelbrecht GCE (2006) Parodiërende en nie-parodiërende verwerkings van Bybelse gegewens in die Afrikaanse poësie sedert 1960 (Parodying and Non-Parodying Adaptations of Biblical Material in Afrikaans Poetry since 1960). Unpublished MA dissertation, University of Stellenbosch, Stellenbosch.

Fokkema DW (1984) Literary History, Modernism and Postmodernism (The Harvard University Erasmus Lectures, Spring, 1983). Amsterdam: John Benjamins Publishing Company.

Foster R (2000) Beelde van die Afrikaanse poësie sedert 1960 (Images of Afrikaans poetry since 1960). Retrieved from http://goo.gl/Y54j3y. [Accessed: 16 May 2011]

Foster R (2001) Postmodernistiese intertekstualiteit as teiken. 'n Bespreking van die jagter-interteks in "Die eland" en Die heengraanrefrein van Wilma Stockenström (Postmodern Intertextuality as Target. A Discussion of the Hunter Intertext in "The Eland" and The Passing Away Refrain by Wilma Stockenström). Stilet 13(3): 17-43.

Foster R, Viljoen L (Eds.) (1997) Poskaarte. Beelde van die Afrikaanse poësie sedert 1960 (Postcards. Images of the Afrikaans Poetry since 1960). Cape Town: Tafelberg.

Galloway F (1990) Breyten Breytenbach as openbare figuur (Breyten Breytenbach as Public Figure). Pretoria: HAUM Literary.

Galloway F, Steenberg DH (1993) Literatuur en konteks in Suid-Afrika in 1985 (Literature and Context in South Africa in 1985). Literator Supplement 1: 1-3.

Gilfillan FR (1991) Die poësie van die tagtigerjare: 'n indruk (The Poetry of the Eighties: an Impression. Stilet 3(1): 47-56.

Giliomee H (2003) The Afrikaners. Biography of a people. Cape Town: Tafelberg.

Giliomee H (2012a) "Aanpas of sterf", 1978-1984 ("Adapt or Die", 1978-1984). In Pretorius F (Eds.) Geskiedenis van Suid-Afrika. Van voortye tot vandag (History of South Africa. From Prehistoric Times to the Present). Cape Town: Tafelberg, pp. 389-403. 
Giliomee H (2012b) Opstand, oorlog en oorgang, 1984-1994 (Revolt, War and Transition, 1984-1994). In Pretorius F (Eds.) Geskiedenis van Suid-Afrika. Van voortye tot vandag (History of South Africa. From Prehistoric Times to the Present). Cape Town: Tafelberg, pp. 405-427.

Grobler J (2012) Swart verset teen apartheid, 1950's-1980's (Black Resistance to Apartheid, 1950s-1980s). In Pretorius F (Eds.) Geskiedenis van Suid-Afrika. Van voortye tot vandag (History of South Africa. From Prehistoric Times to the Present). Cape Town: Tafelberg, pp. 369-388.

Grové AP (1980) Inleiding tot die literatuur van Sestig (Introduction to the literature of Sixty). In: Cloete TT (Eds.) Die Afrikaanse literatuur sedert Sestig (Afrikaans literature since 1960). Goodwood: Nasou Ltd., pp. 1-24.

Hambidge J (1993) Cloete se jongste bundel bevestig vernuf van rym en tegniek (Cloete's Most Recent Collection Confirms Acumen with Rhyme and Technique). Die Burger 26 January: 8.

Hugo D (1996) Die Afrikaanse poësie 1990-1995: 'n Bestekopname in bevooroordeelde flitse (Afrikaans Poetry 1990-1995: A Survey in Prejudiced Flashes). Ensovoort 8(1): 8-10.

Hugo D, Rousseau L, Du Plessis P (Eds.) (2000) Nuwe verset (New Resistance). Pretoria: Protea Book House.

Jacobs I (2010) Begrens én onbegrens: Intertekstualiteit in die oeuvre van H.J. Pieterse (Limited and Unlimited: Intertextuality in the Oeuvre of H.J. Pieterse). Unpublished MA dissertation, North-West University, Potchefstroom.

Johl R (1986) Kritiek in krisis: Vryheid vir die teks (Criticism in Crisis: Freedom for the Text). Durban: Butterworth.

John P (s.a.[I]) Afrikaanse poësie IV: Die Sestigerjare (Afrikaans Poetry IV: The Sixties). Retrieved from http://goo.gl/j9jER8. [Accessed: 16June 2011]

John P (s.a.[II]) Afrikaanse poësie V: Ná 1970 (Afrikaans Poetry V: After 1970), Retrieved from http://goo.gl/a22ASX. [Accessed: 16 June 2011]

Kannemeyer JC (1978) Geskiedenis van die Afrikaanse literatuur I (History of Afrikaans Literature, Volume I). Pretoria: Academica.

Kannemeyer JC (1983) Geskiedenis van die Afrikaanse literatuur II (History of Afrikaans Literature, Volume II). Pretoria: Academica.

Kannemeyer JC (1988) Die Afrikaanse literatuur 1652-1987 (Afrikaans Literature 1652-1987). Pretoria: Academica.

Kannemeyer JC (2005) Die Afrikaanse literatuur 1652-2004 (Afrikaans Literature 1652-2004). Cape Town: Human \& Rousseau.

Kannemeyer JC (2007) "Uit puur verstrooiing". Lesings, praatjies, artikels, onderhoude en besprekings ("From Pure Diversion". Papers, Speeches, Articles, Interviews and Discussions). Stellenbosch: Inset Publishers.

Kleyn L (2008) 'n Ander bestekopname van die Afrikaanse poësie, 2004-2007 (An Alternative Survey of Afrikaans Poetry, 2004-2007). LitNet Academic 5(1). Retrieved from http://goo.gl/hQLcRx. [Accessed: 03 December 2010]

Klopper A (2009) Die opkoms van Afrikaanse rock en die literêre status van lirieke, met spesifieke verwysing na Fokofpolisiekar (The Rise of Afrikaans Rock and the Literary Status of Lyrics, with Specific Reference to [the Rock Group] Fokofpolisiekar). Unpublished MLitt dissertation, University of Stellenbosch, Stellenbosch.

Komrij G (comp.) (1999) Die Afrikaanse poësie in 'n duisend en enkele gedigte (The Afrikaans Poetry in Over a Thousand Poems). Amsterdam: Bert Bakker Publishers. 
Lourens A (2011) Die uitbou van 'n eens marginale tradisie: Marlise Joubert se gebruik van vroulike taal (The Expansion of a Formerly Marginal Tradition). Stilet 33(2): 61-74.

Louw NPvW (1961) Vernuwing in die prosa (Renewal in Prose Fiction). Pretoria: Academica.

Nienaber CJM, Nienaber-Luitingh M (Eds.) (1987) Die braambos brand. 'n Keur uit godsdienstige gedigte (The Bramble Is Burning. A Selection from Religious Poetry). Cape Town: Tafelberg.

Odendaal BJ (2001) Bestekopnametyd? Strategiese funksies van tematiese poësiebloemlesings in die Afrikaanse literêre veld in die tydperk 1986-2000 (Time for Stocktaking? Strategic Functions of Thematic Poetry Anthologies in the Afrikaans Literary Field in the Period 1986-2000). Stilet 13(1): 51-68.

Odendaal BJ (2006) Tendense in die Afrikaanse poësie in die tydperk 1998 tot 2003 (Trends in Afrikaans Poetry in the Period 1998-2003). In Van Coller HP (Eds.) Perspektief en profiel. 'n Afrikaanse literatuurgeskiedenis, Deel 3 (Perspective and Profile. A History of Afrikaans Literature, Part 3). Pretoria: J.L. van Schaik, pp. 105-148.

Ohlhoff H (1999) Perspektief op die Afrikaanse poësie: die poësie van voor 1900 tot 1960 (Perspective on Afrikaans Poetry: the Poetry of the Pre-1900s up to 1960). In Van Coller HP (Eds.) Perspektief en profiel. 'n Afrikaanse literatuurgeskiedenis, Deel 2 (Perspective and Profile. An Afrikaans Literary History, Volume 2). Pretoria: J. L. Van Schaik, pp. 21-243.

Olivier F (Eds.) (1986) Die mooiste Afrikaanse liefdesgedigte (The Most Beautiful Afrikaans Love Poems). Cape Town: Human \& Rousseau.

Olivier F (Eds.) (1992) Die mooiste Afrikaanse liefdesgedigte. 'n Groter keur (The Most Beautiful Afrikaans Love Poems. A Bigger Selection). Cape Town: Human \& Rousseau.

Ponelis F (1993) The Development of Afrikaans. Frankfurt am Main: Peter Lang.

Roodt PH (1991) Rondom die literatuur en kritiek van die tagtigerjare: Elize Botha, Joan Hambidge en Charles Malan in gesprek met P.H. Roodt (About the Literature and Criticism of the 1980s: Elize Botha, Joan Hambidge and Charles Malan in Conversation with P.H. Roodt). Stilet 3(1): 1-20.

Roos H (1998) Perspektief op die Afrikaanse prosa van die twintigste eeu (Perspective on the Afrikaans Prose of the Twentieth Century). In Van Coller H (Eds.) Perspektief en profiel, deel 2 (Perspective and Profile, Part 2). Pretoria: J.L. van Schaik Academic, pp. 21-117.

Spies L (comp.) (1999) Sy sien webbe roer. 'n Keuse uit die werk van Afrikaanse digteresse (She Sees Webs Stirring. A Selection from the Work of Afrikaans Poetesses). Cape Town, Pretoria and Johannesburg: Human \& Rousseau.

Van Coller HP (2002) Prosakroniek (Prose Fiction Chronicle). Tydskrif vir Geesteswetenskappe 42(4): 304-320.

Van Coller HP, Odendaal BJ (2003) Kleur kom nooit alleen nie (Antjie Krog) en Die burg van hertog Bloubaard (H.J. Pieterse): 'n poëtikale beskouing, deel 1 (Colour Does Not Come Alone (Antjie Krog) and The Castle of Duke Bluebeard (H.J. Pieterse): a Poetical View, Part 1). Stilet 15(1): 16-35.

Van Coller HP, Odendaal BJ (2005a) Die verhouding tussen die Afrikaanse en Nederlandse literêre sisteme. Deel 1: Oorwegings vir 'n beskrywende model (The Relationship between the Afrikaans and Dutch Literary Systems. Part 1: Considerations for a Descriptive Model). Stilet 17(3): 1-17.

Van Coller HP, Odendaal BJ (2005b) Die verhouding tussen die Afrikaanse en Nederlandse literêre sisteme. Deel 2: 'n Chronologiese oorsig (The Relationship 
between the Afrikaans and Dutch Literary Systems. Part 2: A Chronological Overview). Stilet 17(3): 18-46.

Van Coller HP, Odendaal BJ (2007) Antjie Krog's Role as Translator: A Case Study of Strategic Positioning in the Current South African Literary Poly-system. Current Writing 19(2): 94-121.

Van Niekerk A (1999) Die Afrikaanse vroueskrywers van egotekste tot postmodernisme (18 eeu - 1996) (The Afrikaans Women Authors from Egotexts to Postmodernism $\left(18^{\text {th }}\right.$ Century - 1996). In Van Coller HP (Eds.) Perspektief en profiel. 'n Afrikaanse literatuurgeskiedenis, Deel 2 (Perspective and Profile. An Afrikaans Literary History, Volume 2). Pretoria: J.L. van Schaik, pp. 305-443.

Van Rensburg C (Eds.) (1997) Afrikaans in Afrika (Afrikaans in Africa). Pretoria: J.L. Van Schaik Academic.

Van Vuuren H (1999) Perspektief op die moderne Afrikaanse poësie (1960-1997) (Perspective on Modern Afrikaans Poetry (1960-1997)). In Van Coller HP (Eds.) Perspektief en profiel. 'n Afrikaanse literatuurgeskiedenis, Deel 2 (Perspective and Profile. An Afrikaans Literary History, Volume 2). Pretoria: J.L. van Schaik, pp. 244-304.

Van Vuuren H (2001) A Perspective on Modern Afrikaans Poetry (1960-2000). Stilet 13(2): $32-50$.

Van Vuuren H (2011) "'n Almanak van klippe": Laatwerk en Breyten Breytenbach se Die beginsel van stof (laat-verse, sprinkaanskaduwees, aandtekeninge) ("An Almanac of Stones": late Work and Breyten Breytenbach's The Principle of Dust (late verse, grasshopper shadows, notes)). LitNet Academic 8(3). Retrieved from http://goo.gl/L5OVlq. [Accessed: 27 May 2013]

Venter MR, Galloway F (2003) Boekkultuur kort dringend 'n inspuiting (Book Culture Urgently Needs Infusion. Die Burger 6 January: 7.

Viljoen H (1990) 'n Potjie representasie, sterk gekruie: representeem en diskontinuïteit in die literatuurgeskiedskrywing (A Bowl of Representation, Seasoned Well: Representym and Discontinuity in Literary Historiography). Literator 11(3): 2-11.

Viljoen H (2010) Groot avonture in die (onlangse) Afrikaanse poësie (Great Adventures in (Recent) Afrikaans Poetry). Stilet 23(2): 169-196.

Viljoen L (2003) Breyten en die vaders: perspektiewe op die rol van die vader in Breytenbach se vroeë poësie (Breyten Breytenbach and the Fathers: Perspectives on the Role of the Father in Breytenbach's Early Poetry). Stilet 15(2): 28-52.

Viljoen L (2009a) Afrikaanse digters in gesprek met Breyten Breytenbach as digter (Afrikaans Poets Conversant with Breyten Breytenbach as a Poet). LitNet Academic 6(3). Retrieved from http://goo.gl/WxOBRb. [Accessed: 21 February 2013]

Viljoen L (2009b) Ons ongehoorde soort. Beskouings oor die werk van Antjie Krog (We, the Unheard Kind. Views on the Work of Antjie Krog). Stellenbosch: SUN Press.

Viljoen L (2011) Of Chisels and Jackhammers: Afrikaans Poetry, 2000-2009. Current Writing 23(1): 17-34. 
